\title{
Liste der Sigla für Glaubenssymbole
}

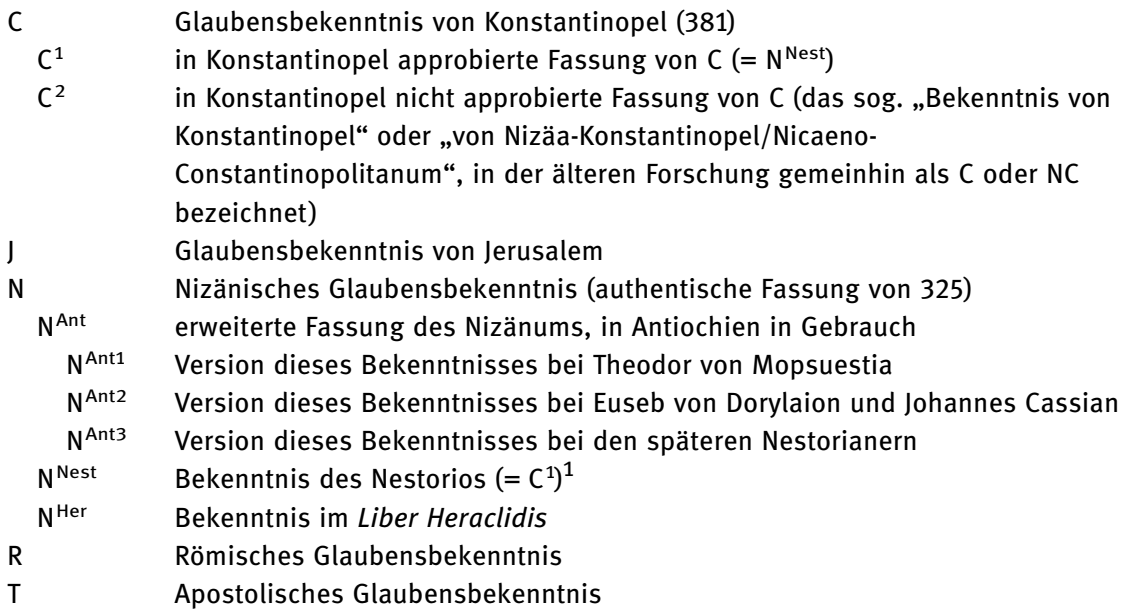

1 In Kinzig, Zwei neuentdeckte Predigten, 2020 habe ich die wesentliche Übereinstimmung zwischen den Symbolzitaten in den bisher bekannten Nestoriostexten (dort als $\mathrm{N}^{\text {Nest }}$ bezeichnet) und in einer neu entdeckten und dort edierten Homilie $\left(\mathrm{N}^{\mathrm{Hom}}\right)$ aufgezeigt, die Nestorios zuzuschreiben sein dürfte. Ich nehme daher an, dass gilt: $\mathrm{N}^{\mathrm{Nest}}=\mathrm{N}^{\mathrm{Hom}}$. Zu den verbleibenden

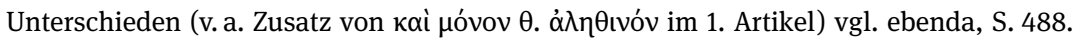

